\title{
Writing Anxiety Among Saudi Female Learners at Some Saudi Universities
}

\author{
Nafilah M. Aloairdhi ${ }^{1}$ \\ ${ }^{1}$ English Language and Translation Department, Qassim University, Qassim, Saudi Arabia \\ Correspondence: Nafilah M. Aloairdhi, English Language and Translation Department, College of Arabic \\ Language and Social Studies, Qassim University, Qassim, Saudi Arabia.
}

Received: May 13, 2019 Accepted: August 8, 2019 Online Published: August 10, 2019

doi: 10.5539/elt.v12n9p55 URL: https://doi.org/10.5539/elt.v12n9p55

\begin{abstract}
Writing is an important skill in language learning and in academic achievement. The level of writing anxiety could affect students' achievements positively or negatively. This research aimed to examine the writing anxiety among Saudi female learners enrolled in English language departments at some Saudi universities. It also aimed to identify the sources of writing anxiety. To this end, a mixed method study was designed in which Writing Apprehension Test (WAT) Scale by Daly and Miller (1975) and an open-ended question were used to collect necessary data from 105 randomly selected learners. For data analysis, two different statistical procedures in Statistical Package for Social Sciences (SPSS) and a specific formula suggested by Daly and Miller (1975) were applied. Coding was applied to qualitative data. The results indicated that the participants $(\mathrm{N}=105)$ experience moderate level of writing anxiety. In addition, the main sources of writing anxiety were evaluation, generating ideas, grammar, time pressure, and lack of confidence.
\end{abstract}

Keywords: L2 writing, writing anxiety, writing apprehension, WAT scale

\section{Introduction}

Writing is an important skill in language learning and in academic achievement. In English as a Foreign Language (EFL) learning, learners are different in their writing abilities for many reasons. One of these reasons is writing anxiety. English language learners need a low-anxiety environment to accomplish their aims in English writing (Salem, 2007). Several studies suggested that learners are different in their anxiety levels (Aljafen, 2013; Ekmekçi, 2018; Elif \& Demet, 2019; Rezaei \& Jafari, 2014). Furthermore, some researchers suggested that anxiety has some sources (Alsowat, 2016). Although many research has been done to investigate the effects of second language (L2) writing anxiety on second language learners, little has been made to investigate the effects of foreign language writing anxiety on foreign language learners (Aljafen, 2013). Therefore, this paper aims to shed more light on the writing anxiety and its sources among Saudi female learners enrolled in English language departments at some Saudi universities. This paper answers two main questions. The first is about the levels of anxiety among Saudi EFL female learners. The second will discuss the potential sources of anxiety among Saudi EFL female learners.

\section{Literature Review}

\subsection{Anxiety and Language Learning}

Anxiety is a psychological concept. Hilgard, Atkinson, and Atkinson (1979) discussed anxiety as recognized by psychologists as a state of concern and apprehension, an ambiguous anxiety that is particularly related to a specific object or phenomenon. As any other psychological problem, anxiety can be experienced in many situations. One of these situations is learning. Learners are different in their propensity to feel anxiety according to the time and situations, but learning a language is one of the factors that prompt anxiety (Al-Saraj, 2014). When anxiety is associated with foreign or second language learning, it is called "foreign/second language anxiety" (Hakim, 2019, p. 65). Language anxiety has been extensively studied in recent years. Language anxiety is "the feeling of tension and apprehension specifically associated with second language contexts" (Maclntyre \& Gardner, 1994, p. 284). Horwitz, Horwitz, and Cope (1986) defined language anxiety as "a distinct complex of self-perceptions, beliefs, feelings, and behaviors related to classroom language learning arising from the uniqueness of the language learning process" (p. 128). Thus, language anxiety has two dimensions: the first is 
related to the language using and learning and the second is related to the language itself (Alsowat, 2016).

According to Sadiq (2017), previous studies have revealed that language anxiety can hinder foreign language production and performance. Furthermore, language anxiety has long been considered as an obstacle in language learning. Also, language researchers showed that the language anxiety affects learners' performance and achievement. Halder (2018) conducted a study to explore the relationship between learners' academic achievement and language anxiety. The results showed a significant negative correlation between learners' academic achievement and language anxiety. Another study about language anxiety and achievement was Marcos-Llinás and Garau's (2009) study. It was conducted to investigate the effects of language anxiety on course achievement in beginning, intermediate, and advanced learners of Spanish as a foreign language. The findings showed that there is a relationship between language anxiety and course achievement. Also, learners from different proficiency levels have different anxiety levels. Beginning and intermediate learners have lower levels of anxiety than advanced learners. Mohammed (2015) also conducted a study to examine the motivational patterns and anxiety levels of Saudi EFL learners and recognize how these two variables affect language learning. The results showed that Saudi EFL learners are demotivated and very anxious toward learning English as a foreign language.

Sadiq (2017) mentioned that language anxiety can be experienced in writing, reading, listening, or speaking and it can affect learners' attitudes negatively toward writing skill. In addition, language anxiety has been considered as an important factor that influences language learner's success or failure.

\subsection{Second Language Writing}

Second language writing is important to academic success since it is the commonest tool to assess second language learners (Tan, 2011). Javadi-Safa (2018) argued that writing is a challenging task for language learners because of its productive and active nature. Also, second language writing is an emotional and a cognitive task.

Erkan and Saban (2011) tried to identify whether writing performance of Turkish tertiary-level EFL learners is related to writing apprehension, self-efficacy, and/or attitudes towards writing. They found that these affective components provided a significant evidence in writing performance in EFL learners. In another study to investigate some affective factors in second language writing, Gupta and Woldemariam (2011) found that instrumental motivation is one main variable in improving writing skills. The findings of these studies suggested that affective factors like writing apprehension, motivation, and students' beliefs and attitudes can affect second language writing.

\subsection{Second Language Writing Anxiety}

Second language writing anxiety is "generally understood to mean negative, anxious feelings that disrupt some part of the writing process" (McLeod, 1987, p. 427). Some students find writing "an uncomfortable, punishing, and even fearful experience" (Teichman \& Poris, 1989, p. 94). Bothma and Cloete (1964, as cited in Olivier \& Olivier, 2016) argued that most students experience writing as an "artificial and not very pleasant activity" (p. 2). Karakaya and Ülper (2011) stressed that learners who have writing anxiety find writing process challenging and demanding. Moreover, they assured that "anxiety is a critical and decisive notion in language learning process and writing process" (p. 704).

Previous studies have shown that second language writing anxiety affects learners' performance, achievement, and attitudes negatively. Aljafen (2013), for example, conducted a study to investigate writing anxiety and its sources among Saudi male learners and instructors in EFL science departments at Qassim University in Saudi Arabia. The scale that was used to measure learners' writing anxiety was English Writing Apprehension/Attitude Test (EWAT) Scale. The findings of the research revealed that all the subjects experience almost the same moderate level of writing anxiety.

In another study, Masriani, Mukhaiyar, and Wahyuni (2018) investigated the second language writing strategies and the levels of writing anxiety among learners enrolled in English language departments of Universitas Negeri Padang. The scale that was used to measure students' writing anxiety was Second Language Writing Anxiety Inventory (SLWAI). The results showed that all the participants have moderate level of second language writing anxiety.

In their study, Elif and Demet (2019) captured the writing anxiety sources and levels of group of Turkish EFL learners studying at a preparatory school. They used (SLWAI) Scale to present quantitative data and open-ended questionnaire and interviews to present qualitative data. They found that the participants have high to moderate levels of writing anxiety.

Another study that has been conducted to find out the levels and types of writing anxiety and to find if there is a 
statistically significance difference between beginning and advanced learners in terms of anxiety types and levels is Ekmekçi's (2018) study. The participants were prospective teachers of English enrolled in English Language Teaching (ELT) department at a Turkish university. Using (SLWAI) Scale, the results showed that $60 \%$ of the participants experience moderate level of writing anxiety. In a similar study, Rezaei and Jafari (2014) examined writing anxiety types, levels, and causes among Iranian EFL learners. The results showed that the participants have high level of writing anxiety.

\subsection{Sources of Second Language Writing Anxiety}

According to Alsowat (2016), identifying the sources of second language writing anxiety can provide more understanding to the anxiety nature. It can also help teachers and instructors to find new strategies to reduce learners' second language writing anxiety. Zheng (2008) argued that the sources of language anxiety are personal and interpersonal, learners' beliefs, teachers' beliefs about anxiety, interactions between teachers and learners, language testing, and classrooms procedures. Also, motivation, proficiency level, teachers, language skills, the level of the course, and culture are recognized as main sources of language anxiety (Alsowat, 2016). Furthermore, pressure from parents or language instructors, personality factors, and fear of being evaluated negatively are from the sources of language anxiety (Jen, 2003). Aljafen (2013) also added gender issue and level of writing experience to the sources of writing anxiety. Daly and Miller (1975) suggested that novice and intermediate learners are more anxious than advanced learners who enrolled in writing classes.

Several studies have tried to focus on the sources of second language writing anxiety. One of these studies is Aljafen's (2013) study. He found that the main sources of anxiety are weak English education, lack of confidence, and evaluation. Another study is Rezaei and Jafari's (2014) study. The causes of writing anxiety in Rezaei and Jafari's (2014) study are high expectations, lack of confidence, fear of negative feedback, and weak linguistic knowledge. Moreover, in their study, Elif and Demet (2019) considered exams, the selection of the topic, time pressure, finding ideas, and insufficient effective feedback the most anxiety-provoking factors. Then, they are followed by grammar, organizing ideas, and brainstorming. One more study is Kusumaningputri, Ningsih, and Wisasongko's (2018) study. They conducted a study to identify the sources of writing anxiety among a group of Indonesian students writers in their first and second year of college. The findings revealed that the sources of anxiety for the first-year students are time pressure, insufficient practice, and linguistic difficulties. On the other hand, the sources of anxiety for the second-year students are linguistic difficulties, insufficient practice, and insufficient writing techniques.

As reviewed in the literature, second language writing anxiety is an affective factor that can hinder learning and writing. Also, second language writing anxiety was investigated among Saudi male learners enrolled in EFL science departments. Therefore, this research will try to shed more light on this issue and identify its sources among Saudi female learners enrolled in English language departments at Saudi universities.

\subsection{Research Questions}

This research addressed the following questions:

1) Do Saudi female learners enrolled in English language departments at Saudi universities experience writing anxiety when writing in English?

2) What are the potential sources of writing anxiety from the Saudi female learners' point of view?

\section{Methodology}

\subsection{Research Design}

The main aim of this research is to answer the research questions. To achieve this, one adopted scale to measure writing anxiety will be used to collect numerical data to answer the first question and one open-ended question will be provided to collect qualitative data to answer the second question. Thus, the design of this research is mixed method design. The mixed method was chosen to get deeper insights and opinions from the subjects and to let them explain all the reasons of their anxiety.

\subsection{Data Collection Method}

For the aims of this research, it has been decided to choose an adopted scale and to add one open-ended question. The scale is Writing Apprehension Test (WAT) that has been developed by Daly and Miller in 1975 (Daly \& Miller, 1975). The reliability coefficient of WAT Scale is .921 (Daly \& Miller, 1975). According to Aljafen (2013), many researchers have used this scale to measure writing anxiety. It was thought that WAT Scale with its reliability and clarity, especially in EFL contexts, would be a good choice to be used in this study.

The open-ended question was formulated to know the potential sources of writing anxiety from the subjects' 
point of view.

\subsubsection{The Open-Ended Question and WAT Scale}

WAT is a questionnaire that contains 26 statements. It contains 13 statements with negative meanings (i.e., 1, 4, 5, $7,8,13,16,18,21,22,24,25$, and 26) and 13 statements with positive meanings (i.e., 2, 3, 6, 9, 10, 11, 12, 14, $15,17,19,20$, and 23). These statements are Likert Scale based statements consisting of the following values: (1) strongly agree, (2) agree, (3) are uncertain, (4) disagree, or (5) strongly disagree. The open-ended question was: "From your point of view as an EFL female learner, what is the source of any writing anxiety that you may have?" It was formulated to identify the sources of writing anxiety that the students think they have. Writing Apprehension Test (WAT) by Daly and Miller (1975) and the open-ended question are shown in Appendix A.

\subsubsection{The Subjects}

The target population of this study was Saudi female learners enrolled in English language departments at some Saudi universities. The subjects completed some English writing courses throughout their EFL study. Their age was ranging from 19 to 23 years. They have been studying English for six years at least before enrolling in English language departments. The sample was selected randomly and the number of responses was $117(\mathrm{~N}=$ 117).

It was decided to choose random sampling technique because it allows investigating writing anxiety among learners from different proficiency levels, backgrounds, writing skills, and teaching styles. Also, it was hoped to collect a large number of responses of the subjects to get deeper explanation and description of the writing anxiety.

\subsubsection{The Procedure}

This research was done during the second semester of the academic year 2018-2019. By using Googledocs, the WAT Scale and the open-ended question were available online to the subjects from the $21^{\text {st }}$ of March until the $7^{\text {th }}$ of April. The electronic link of the questionnaire was distributed among some of the target population, and the subjects were randomly selected. For the ethical considerations, all the necessary information and instructions for the subjects were included in the introduction of the questionnaire.

\subsection{Data Analysis}

After the collection data procedure has done, it was reviewed that all the responses, received from 117 Saudi female learners $(\mathrm{N}=117)$, were complete in WAT Scale. It was found that the complete responses are $105(\mathrm{~N}=105)$ in WAT and 45 in the optional question. Therefore, the quantitative analysis was applied only to the complete responses $(\mathrm{N}=105)$ and the qualitative analysis was applied to 45 responses. Then, by using Googledocs figures and Excel tables, data were prepared to be analysed by using Statistical Package for Social Sciences (SPSS). Descriptive statistics and Pearson correlation were used to analyse data by using SPSS. In addition to these two procedures, one specific formula suggested by Daly and Miller (1975) was applied to measure the levels of writing anxiety. On the one hand, the statistics were used to report the mean (M), standard deviation (SD), and percentages. On the other hand, the Pearson correlation was used to correlate the positive and negative statements with the strongest positive or negative statements.

\section{Analysis and Results}

As mentioned earlier, the aim of this research is to answer two questions. The first is: "Do Saudi female learners enrolled in English language departments at Saudi universities experience writing anxiety when writing in English?", while the second is: "What are the potential sources of writing anxiety from the Saudi female learners' point of view?" To this end, an open-ended question an adopted questionnaire (WAT Scale) that contained 26 Likert Scale based statements were provided to a random sample of Saudi female learners enrolled in English language departments at some Saudi universities.

\subsection{Statistical Procedures}

\subsubsection{Descriptive Statistics}

These statistics were used to report the mean (M) and standard deviation (SD) for the positive and negative statements. Table 1 shows the mean and standard deviation for the negative statements. The writing anxiety was examined based on the Daly and Miller's (1975) values: (1) strongly agree, (2) agree, (3) are uncertain, (4) disagree, or (5) strongly disagree. Thus, when a subject gets high points, this means that she does not experience anxiety. On the other hand, when a subject gets low points, this means that she experiences writing anxiety. According to Daly and Miller (1975), when subjects' points are more than 3, then this indicates that these subjects do not experience real problem with writing anxiety. Table 1 shows that 10 statements out of 13 were averaged 
more than 3. Therefore, the participants do not experience high level of anxiety. Also, the lowest point indicates the most anxiety-provoking factor. For example, "My mind seems to go blank when I start to work on my composition" with 2.61 mean is considered as a first factor that provokes writing anxiety. However, the overall score for the negative statements is $(\mathrm{M}=3.17$; $\mathrm{SD}=.79)$ which indicated that Saudi female learners do not experience real problems with writing anxiety. Table 1 presents the results of all negative statements.

Table 1. The mean and standard deviation for the negative statements

\begin{tabular}{lll}
\hline Negative statements & Mean & Std. Deviation \\
\hline I avoid writing. & 3.44 & 1.23 \\
I am afraid of writing essays when I know they will be evaluated. & 2.85 & 1.24 \\
Taking a composition course is a very frightening experience. & 3.34 & 1.17 \\
My mind seems to go blank when I start to work on my composition. & 2.61 & 1.18 \\
Expressing ideas through writing seems to be a waste of time. & 3.90 & 1.11 \\
I am nervous about writing. & 3.06 & 1.20 \\
I never seem to be able to write down my ideas clearly. & 3.31 & 1.06 \\
I expect to do poorly in composition classes even before I enter them. & 3.20 & 1.20 \\
I have a terrible time organising my ideas in a composition course. & 2.69 & 1.17 \\
When I hand in a composition, I know I am going to do poorly. & 3.33 & 1.00 \\
I do not think I write as well as most other people do. & 2.92 & 1.11 \\
I do not like my compositions to be evaluated. & 3.08 & 1.16 \\
I am not good at writing. & 3.50 & 1.18 \\
Negative statements & 3.17 & 0.79 \\
\hline
\end{tabular}

For the positive statements, the analysis will be the opposite because (strongly agree) value is lower than (strongly disagree) value. Therefore, learners with high points would experience writing anxiety. For example, "It is easy to me to write good compositions" with 3.03 mean is an action the does not provoke anxiety. Table 2 shows the results of all positive statements.

Table 2. The mean and standard deviation for the positive statements

\begin{tabular}{lll}
\hline Positive statements & Mean & Std. Deviation \\
\hline I have no fear of my writing being evaluated. & 3.39 & 1.16 \\
I look forward to writing down my ideas. & 3.90 & 0.90 \\
Handing in a composition makes me feel good. & 3.59 & 0.90 \\
I would enjoy submitting my writing to magazines for evaluation and publication. & 3.23 & 1.07 \\
I like to write down my ideas. & 3.90 & 0.99 \\
I feel confident in my ability to express my ideas clearly in writing. & 3.64 & 1.07 \\
I like to have my friends read what I have written. & 3.40 & 1.19 \\
People seem to enjoy what I write. & 3.22 & 0.89 \\
I enjoy writing. & 3.47 & 1.25 \\
Writing is a lot of fun. & 3.33 & 1.21 \\
I like seeing my thoughts on paper. & 3.93 & 0.86 \\
Discussing my writing with others is enjoyable. & 3.58 & 1.05 \\
It is easy for me to write good compositions. & 3.03 & 1.04 \\
Positive statements & 3.51 & 0.68 \\
\hline
\end{tabular}




\subsubsection{Pearson Correlation}

Pearson correlation was used to correlate negative statements and positive statements with the most general statements in both negative and positive sections. Negative statements were correlated with the most general statement among negative statements: "I am nervous about writing". Table 3 shows that all negative statements have a significant correlation with "I am nervous about writing".

Table 3. Negative correlation of statements

\begin{tabular}{|c|c|c|}
\hline & \multicolumn{2}{|c|}{ I am nervous about writing. } \\
\hline & Pearson Correlation & Sig. (2-tailed) \\
\hline I avoid writing. & $.529 * *$ & $<0.0001$ \\
\hline I am afraid of writing essays when I know they will be evaluated. & $.582 * *$ & $<0.0001$ \\
\hline Taking a composition course is a very frightening experience. & $.329 * *$ & 0.001 \\
\hline My mind seems to go blank when I start to work on my composition. & $.620 * *$ & $<0.0001$ \\
\hline Expressing ideas through writing seems to be a waste of time. & $.410 * *$ & $<0.0001$ \\
\hline I never seem to be able to write down my ideas clearly. & $.531 * *$ & $<0.0001$ \\
\hline I expect to do poorly in composition classes even before $I$ enter them. & $.465 * *$ & $<0.0001$ \\
\hline I have a terrible time organising my ideas in a composition course. & $.417 * *$ & $<0.0001$ \\
\hline When I hand in a composition, I know I am going to do poorly. & $.466^{* *}$ & $<0.0001$ \\
\hline I do not think I write as well as most other people do. & $.409 * *$ & $<0.0001$ \\
\hline I do not like my compositions to be evaluated. & $.475 * *$ & $<0.0001$ \\
\hline I am not good at writing. & $.599 * *$ & $<0.0001$ \\
\hline
\end{tabular}

**. Correlation is significant at the 0.01 level (2-tailed).

For the positive statements, they were correlated with the most general statement: "I enjoy writing." Table 4 shows that all the positive statements have a significant correlation with "I enjoy writing".

Table 4. Positive correlation of statements

\begin{tabular}{lll}
\hline & \multicolumn{2}{l}{ I enjoy writing. } \\
\cline { 2 - 3 } & \multicolumn{1}{l}{ Pearson Correlation } & Sig. (2-tailed) \\
\hline I have no fear of my writing being evaluated. & $.472^{* *}$ & $<0.0001$ \\
I look forward to writing down my ideas. & $.423^{* *}$ & $<0.0001$ \\
Handing in a composition makes me feel good. & $.379^{* *}$ & $<0.0001$ \\
I would enjoy submitting my writing to magazines for evaluation and publication. & $.453^{* *}$ & $<0.0001$ \\
I like to write down my ideas. & $.538^{* *}$ & $<0.0001$ \\
I feel confident in my ability to express my ideas clearly in writing. & $.359^{* *}$ & $<0.0001$ \\
I like to have my friends read what I have written. & $.242^{*}$ & 0.013 \\
People seem to enjoy what I write. & $.579^{* *}$ & $<0.0001$ \\
Writing is a lot of fun. & $.332^{* *}$ & 0.001 \\
I like seeing my thoughts on paper. & $.772^{* *}$ & $<0.0001$ \\
Discussing my writing with others is enjoyable. & $.550^{* *}$ & $<0.0001$ \\
It is easy for me to write good compositions. & $.384^{* *}$ & $<0.0001$ \\
\hline
\end{tabular}

**. Correlation is significant at the 0.01 level (2-tailed). 
*. Correlation is significant at the 0.05 level (2-tailed).

+In sum, it is clear from Table 3 and Table 4 that the positive statements supported the other positive ones, and the negative statements supported the other negative ones.

\subsubsection{Writing Anxiety Levels}

The levels of writing anxiety among the subjects were explored. According to Daly and Miller (1975), the formula that should be used to identify the levels of writing anxiety is as follows: WA $=78+$ PSV - NSV. It means: Writing Apprehension, or Anxiety, $=78+$ Positive Scores Values - Negative Scores Values. The highest score is 130 and the lowest is 26. Daly and Miller (1975) clarified that the scores that are ranging from 26 to 59 indicate high level of writing anxiety, the scores that are ranging from 60 to 96 indicate moderate level of writing anxiety (i.e., not significantly unusual), and the scores that are ranging from 97 to 130 indicate low level of writing anxiety. The formula was applied to each subject. The results show that all the subjects have a moderate level of writing anxiety. Table 5 shows the subjects' writing anxiety level.

Table 5. Subjects' writing anxiety level

\begin{tabular}{lll}
\hline & Frequency & Percent \\
\hline $\mathbf{2 6 - 5 9}$ & 0 & 0.0 \\
$\mathbf{6 0 - 9 6}$ & 105 & 100.0 \\
$\mathbf{9 7 - 1 3 0}$ & 0 & 0.0 \\
\hline
\end{tabular}

\subsection{Qualitative Analysis}

The open-ended question was formulated to know the potential sources of writing anxiety from the subjects' point of view. After revising the responses, they were grouped into shared themes. After that, they were organized from the most anxiety-provoking sources to the least in each category.

The results show that the most anxiety-provoking source is fear of being judged or evaluated. One of learners explained her fears of being judged by saying: "The fact that my writing is being evaluated is the main source of anxiety for me." Another student said: "When I get judged badly in front of people who I admire.. [sic] I used to have this anxiety but I get ride [sic] of it successfully after few months. Thank you." The results also reveal that the difficulty of generating ideas is considered as the second source. One learner explained this by saying: "Not having a good enough idea to write about." Another source is grammatical issues. One student mentioned: "Grammar structure" as an answer. Also, lack of confidence is considered as a main source. One of the students said: "I don't trust myself because I get a bad mark in writing section in IELTS." Time pressure is one of the main sources. One learner mentioned: "certain deadline" as a source of writing anxiety. Table 6 shows the main sources of writing anxiety.

Table 6. Sources of writing anxiety

\begin{tabular}{lll}
\hline Classroom Practices & 1. & Time pressure. \\
& 2. & A. Insufficient practice. B. Topic selection. \\
& 3. & Way of evaluation. \\
& 4. & Negative feedback. \\
\hline Ideas & 1. & Difficulty of generating ideas. \\
& 2. & Difficulty of organizing ideas. \\
\hline Linguistic Sources & 1. & Grammatical issues. \\
& 2. & Spelling issues. \\
& 3. & A. Sentence order. B. Unity. C. Vocabulary. \\
\hline Personal Sources & 1. & Lack of experience. \\
& 2. & Sharing writings with friends. \\
\hline
\end{tabular}




\begin{tabular}{lll}
\hline & 3. & Writing is not enjoyable activity. \\
\hline Psychological Sources & 1. & Fear of being judged/evaluated. \\
2. & Lack of confidence. \\
3. & Fear of mistakes. \\
\hline
\end{tabular}

\subsection{Research Main Findings}

The main findings of this research can be summarized as follows:

1) The subjects (i.e., Saudi female learners enrolled in English language departments at some Saudi universities) experience moderate level of writing anxiety.

2) The most anxiety-provoking source from the subjects' point of view is evaluation. They also believe that generating ideas, grammar, time pressure, and lack of confidence are from the main sources of writing anxiety.

\section{Discussion}

One of the main aims of this research was to examine the levels of writing anxiety among Saudi female learners studying English language. It was found that all the learners have a moderate level of writing anxiety. This result is consistent and goes in line with some previous studies (e.g., Aljafen, 2013; Ekmekçi, 2018; Masriani et al., 2018). On the other hand, some studies revealed that the sample learners experience high to moderate levels of writing anxiety (e.g., Elif \& Demet, 2019), while some studies showed that the sample learners have high level of writing anxiety (e.g., Rezaei \& Jafari, 2014). However, the literature reviewed in this research suggests that most students experience moderate level of writing anxiety.

The moderate level of writing anxiety among the subjects can be interpreted as they may have weak past English writing experience. Also, it can be that they are evaluated in a way that does not preferable to them. Moreover, the grading policy may increase the anxiety among the students. Another interpretation is that some learners may find English writing unacceptable for some cultural reasons. These cultural reasons may include ethnocentricity, paying much attention to social relationships since they are belonging to an EFL society, and some wrong religious beliefs about foreign languages. Practices inside classrooms may increase writing anxiety. For example, as discussed earlier, the teachers' belief about anxiety affects learners' writing anxiety.

The second aim of this research was to identify the sources of writing anxiety from the subjects' point of view. Most of the learners believe that the evaluation, generating ideas, grammar, time pressure, and lack of confidence are from the main sources of writing anxiety. Also, some of them believe that insufficient practice, lack of experience, and topic selection are sources of writing anxiety. The sources that were expressed by the learners are similar to the sources that have been considered in some studies (e.g., Aljafen, 2013; Elif \& Demet, 2019; Kusumaningputri et al., 2018; Rezaei \& Jafari, 2014).

One of the sources of writing anxiety that was mentioned by the subjects is evaluation. Being afraid of evaluation can be understood as the learners are corrected, for example, in a way that may harm them. Furthermore, it is suggested that the learners are afraid of evaluation because they are not motivated enough. They may study just to pass courses, not to learn how to write. Learners also considered the difficulty of generating ideas as a source of writing anxiety. This may be attributed to the insufficient time provided to writing courses, which in turn may affect writing processes. Another sources were linguistic sources (e.g., grammar and spelling). These sources may be found because of poor prior experience, time pressure, lack of focus, or the educational system practiced in Saudi Arabia which focusses on grammar and spelling when teaching English in general and writing skill in particular. Lack of confidence is one of the sources that is widely considered as a writing anxiety source. Lack of confidence may occur because of the way of evaluation or correction and negative feedback.

\section{Conclusion}

Since writing anxiety has been considered as being obstacle in language learning and academic achievement, identifying it would be necessary. This research strived to shed light on writing anxiety and its sources. It was found that the subjects experience moderate level of writing anxiety and that the evaluation is the most anxiety-provoking factor. Consequently, it was believed that writing anxiety can hinder learning and affect performance.

As was discussed in this paper, the effects of writing anxiety were noticeable. Thus, it can be suggested that educators, teachers, and learners should cooperate to find more solutions to overcome this problem. It is hoped 
that finding some solutions to writing anxiety problem may make language learning and writing more effective.

\subsection{Limitations of the Research}

This research was limited to include only some Saudi female learners. Also, only learners in English language departments at some Saudi universities were selected to be the target population. In addition, the tools of this research were only WAT Scale and one open-ended question. Conducting studies without those limitations might reveal some interesting findings.

\subsection{Recommendations}

The findings of this study have a number of important implications for future practice. For example, to help students have sufficient practice and experience, writing in English might be introduced to them from an early stage in the educational system. Additionally, to increase students' confidence, teachers might make them grade their classmates' writings sometimes. Finally, asking students to write sometimes about topics they like could be an effective method to overcome one of the sources of writing anxiety mentioned by the students; namely topic selection.

\subsection{Future Direction}

More research needs to be done to investigate writing anxiety. Investigating writing anxiety among Saudi learners could make the language learning more effective. Comparing male with female learners, students (males and females) from departments other than English where the means of instruction is English can serve pedagogy and provide more insights to be considered.

\section{References}

Aljafen, B. S. (2013). Writing anxiety among EFL Saudi students in science colleges and departments at a Saudi university (Unpublished master's thesis). Indiana University of Pennsylvania, Indiana, PA.

Al-Saraj, T. M. (2014). Revisiting the foreign language classroom anxiety scale (FLCAS): The anxiety of female English language learners in Saudi Arabia. L2 Journal, 6(1), 50-76. https://doi.org/10.5070/L26121650

Alsowat, H. H. (2016). Foreign language anxiety in higher education: A practical framework for reducing FLA. European Scientific Journal, 12(7), 193-220. https://doi.org/10.19044/esj.2016.v12n7p193

Daly, J. A., \& Miller, M. D. (1975). The empirical development of an instrument to measure writing apprehension. Research in the Teaching of English, 9(1), 242-249.

Ekmekçi, E. (2018). Exploring Turkish EFL students' writing anxiety. The Reading Matrix: An International Online Journal, 18(1), 158-175.

Genç, E., \& Yaylı, D. (2019). The second language writing anxiety: The perceived sources and consequences. PAU Journal of Education, 45(1), 235-251. https://doi.org/10.9779/PUJE.2018.231

Erkan, D. Y., \& Saban, A. I. (2011). Writing performance relative to writing apprehension, self-efficacy in writing, and attitudes towards writing: A correlational study in Turkish tertiary-level EFL. Asian EFL Journal, 13(1), 164-192.

Gupta, D., \& Woldemariam, G. S. (2011). The influence of motivation and attitude on writing strategy use of undergraduate EFL students: Quantitative and qualitative perspectives. Asian EFL Journal, 13(2), 34-89.

Hakim, B. M. (2019). A study of language anxiety among English language learners in Saudi Arabia. Arab World English Journal (AWEJ), 10(1), 64-72. https://doi.org/10.24093/awej/vol10no1.6

Halder, U. K. (2018). English language anxiety and academic achievement. North Asian International Research Journal of Social Science \& Humanities, 4(3), 138-147.

Hilgard, E. R., Atkinson, R. C., \& Atkinson, R. L. (1979). Introduction to psychology. New York, NY: Harcourt Brace Jovanovich.

Horwitz, E. K., Horwitz, M. B., \& Cope, J. A. (1986). Foreign language classroom anxiety. The Modern Language Journal, 70(2), 125-132. https://doi.org/10.1111/j.1540-4781.1986.tb05256.x

Javadi-Safa, A. (2018). A brief overview of key issues in second language writing teaching and research. International Journal of Education \& Literacy Studies, 6(2), 15-25. https://doi.org/10.7575/aiac.ijels. v.6n.2p. 15

Jen, C. Y. (2003). Anxiety in English language classrooms: An investigation of Taiwanese secondary school students' foreign language anxiety in four classroom contexts (Unpublished master's thesis). University of 
Bristol, Bristol, UK.

Karakaya, I., \& Ülper, H. (2011). Developing a writing anxiety scale and examining writing anxiety based on various variables. Educational Sciences: Theory \& Practice, 11(2), 703-707.

Kusumaningputri, R., Ningsih, T. A., \& Wisasongko. (2018). Second language writing anxiety of Indonesian EFL students. Lingua Cultura, 12(4), 357-362. https://doi.org/10.21512/lc.v12i4.4268

Maclntyre, P. D., \& Gardner, R. C. (1994). The subtle effects of language anxiety on cognitive processing in the second language. Language Learning, 44(2), 283-306. https://doi.org/10.1111/j.1467-1770.1994.tb01103.x

Marcos-Llinás, M., \& Garau, M. J. (2009). Effects of language anxiety on three proficiency-level courses of Spanish as a foreign language. Foreign Language Annals, 42(1), 94-111. https://doi.org/10.1111/ j.1944-9720.2009.01010.x

Masriani, E., Mukhaiyar, M., \& Wahyuni, D. (2018). Writing anxiety and writing strategies used by English department students of universitas Negeri Padang. Lingua Didaktika: Jurnal Bahasa dan Pembelajaran Bahasa, 12(1), 76-85.

McLeod, S. (1987). Some thoughts about feelings: The affective domain and the writing process. College Composition and Communication, 38(4), 426-435. https://doi.org/10.2307/357635

Mohammed, A. (2015). EFL effective factors: Anxiety and motivation and their effect on Saudi college student's achievement. Arab World English Journal (AWEJ), 6(2), 201-218. https://doi.org/10.24093/awej/vol6no2.16

Olivier, L., \& Olivier, J. (2016). Exploring writing apprehension amongst Afrikaans-speaking first-year students. Journal of the Reading Association of South Africa, 7(1), 1-10. https://doi.org/10.4102/rw.v7i1.89

Rezaei, M., \& Jafari, M. (2014). Investigating the levels, types, and causes of writing anxiety among Iranian EFL students: A mixed method design. Procedia - Social and Behavioral Sciences, 98(1), 1545-1554. https://doi.org/10.1016/j.sbspro.2014.03.577

Sadiq, J. M. (2017). Anxiety in English language learning: A case study of English language learners in Saudi Arabia. English Language Teaching, 10(7), 1-7. https://doi.org/10.5539/elt.v10n7p1

Salem, M. S. (2007). The effect of journal writing on writing performance, writing apprehension, and attitudes of Egyptians English majors (Unpublished doctoral dissertation). The Pennsylvania State University, Pennsylvania, PA.

Silva, T., \& Leki, I. (2004). Family matters: The influence of applied linguistics and composition studies on second language writing studies-past, present, and future. The Modern Language Journal, 88(1), 1-13. https://doi.org/10.1111/j.0026-7902.2004.00215.x

Tan, B. H. (2011). Innovative writing centers and online writing labs outside North America. Asian EFL Journal, 13(2), 391-418.

Teichman, M., \& Poris, M. (1989). Initial effects of word processing on writing quality and writing anxiety of freshman writers. Computers and the Humanities, 23(2), 93-103. https://doi.org/10.1007/BF00144729

Zheng, Y. (2008). Anxiety and second/foreign language learning revisited. Canadian Journal for New Scholars in Education, 1(1), 1-12.

Zhou, J. (2017). Foreign language reading anxiety in a Chinese as a foreign language context. Reading in a Foreign Language, 29(1), 155-173.

\section{Appendix A}

Writing Apprehension Test (WAT) by Daly and Miller (1975) and The Open-ended Question

I am conducting a research on the second language writing anxiety among Saudi EFL female learners enrolled in English language departments. Obtaining feedback from EFL female learners is important to complete this work. I would appreciate your taking the time to complete the following questionnaire. It should take about 10 minutes of your time. Your responses are voluntary and will be confidential. Thank you. 
Daly and Miller's Writing Apprehension Test

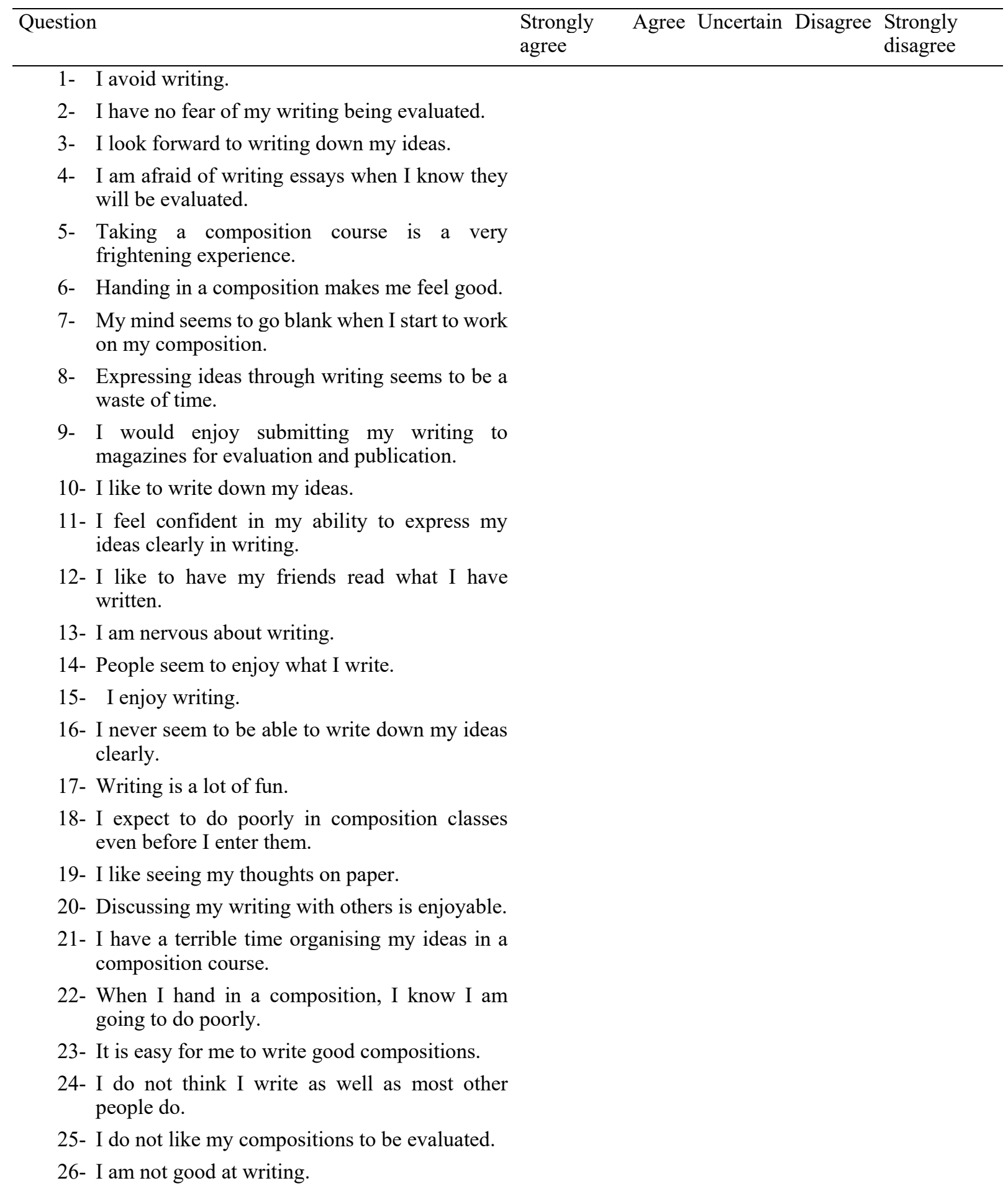

From your point of view as an EFL female learner, what is the source of any writing anxiety that you may have?

\section{Copyrights}

Copyright for this article is retained by the author(s), with first publication rights granted to the journal.

This is an open-access article distributed under the terms and conditions of the Creative Commons Attribution license (http://creativecommons.org/licenses/by/4.0/). 